\title{
Influence of Integrated Membrane Treatment on the Phytotoxicity of Wastewater from the Coke Industry
}

\author{
Marzena Smol • Dariusz Włóka • Maria Włodarczyk-Makuła
}

Received: 11 January 2018 /Accepted: 12 April 2018/Published online: 30 April 2018

(C) The Author(s) 2018

\begin{abstract}
In this paper, coke wastewater that had passed through biological and integrated membrane processes (filtration on sand bed-reverse osmosis) was chosen to assess the phytotoxicity of selected industrial wastewater with regard to the test plant-Vicia faba. An innovative research technique in vitro test was conducted in a large scale phytothrone chamber on two matrices: cotton and Murashige and Skoog Basal Medium (MSBM). The toxicity of wastewater was evaluated for samples: (1) treated in the treatment plant by biological processes, (2) filtrated through a sand bed and filtrated (3) reverse osmosis (RO) membrane. The results showed that there is a noticeable correlation between increasing concentrations of wastewater and seed germination of the test plant. Although the wastewater collected from the coke plant was treated biologically, it showed very high levels of germination inhibition (90-98\% for cotton matrix and 92-100\% for MSBM matrix) and strong toxic effects. The wastewater
\end{abstract}

M. Smol $(\bowtie)$

Mineral and Energy Economy Research Institute, Polish Academy of Sciences, 31-261 Cracow, Poland

e-mail: smol@meeri.pl

D. Włóka

Institute of Environmental Engineering, Faculty of Infrastrcture and Environment, Czestochowa University of Technology,

42-200, Czestochowa, Poland

e-mail: d.wloka@is.pcz.czest.pl

M. Włodarczyk-Makuła

Department of Chemistry, Water and Wastewater Technology,

Faculty of Infrastrcture and Environment, Czestochowa

University of Technology, 42-200, Czestochowa, Poland

e-mail: mwm@is.pcz.czest.pl collected from the coke plant showed a significantly greater phytotoxic effect compared with those obtained from the effluent treated on a sand bed and in RO. However, wastewater, even after treatment on a sand bed (reduction of COD-39\%, TN-46\%, TOC $-42 \%$, TC $-47 \%$, SS-50\%, 16PAHs-53\%), was still toxic and germination inhibition was in the range of $24-48 \%$ for the cotton matrix and $14-54 \%$ for the MSBM matrix. The toxicity of wastewater treated in the membrane process was the lowest (reduction of COD $-85 \%$, TN$95 \%$, TOC $-85 \%$, TC $-86 \%$, SS-98\%, 16PAHs$67 \%$ ). The germination inhibition was in the range of 4 $10 \%$ for the cotton matrix and $2-12 \%$ for the MSBM matrix. These samples are classified as non-toxic or slightly toxic to the model plant. The present study highlights the necessity of monitoring not only the basic physical and chemical indicators (including the level of toxic substances as PAHs), but also their effect on the test organisms in wastewater samples.

Keywords Coke wastewater. Wastewater treatment . Gemination inhibition - Phytotoxicity . Toxity test . Polycyclic aromatic hydrocarbons (PAHs)

\section{Introduction}

One of the most hazardous industrial effluents is wastewater generated during the process of coke production (Macherzyński et al. 2014) and the treatment and processing of coking by-products (Zhao et al. 2015). Coke wastewater contains sizable amounts of ammonium 
salts and compounds such as phenols, oils, tars, suspensions, polycyclic aromatic hydrocarbons (PAHs), toxic organic nitrogen compounds, cyanide, ammonia and hydrogen sulphide (Pillai and Gupta 2016). Raw coke wastewater contains the above toxic impurities and it cannot be sent to the receiver without purification (Włodarczyk-Makuła et al. 2016). Coke wastewater is initially directed to treatment installations located in the area of the coking plant. The most widely used method in such installations is a biological process (Wu et al. 2016), which in many cases is insufficient. It is recommended to use of integrated systems connecting classic unit processes technology used in the treatment (biological, chemical and physical) (Bodzek and Dudziak 2006). The membrane techniques are high effective in the removal of pollutants from aquatic solutions (Kamińska et al. 2016). However, even after integrated treatment, coke wastewater can be still toxic for evrironment. One of the ways to assess the degree of toxicity of wastewater, apart from the determination of the physical and chemical indicators (Paździor et al. 2016; Generowicz et al. 2011), is the toxicity test (da Costa Filho et al. 2016). Currently, tests based on plant bioindicators (Rorat et al. 2014) are often recommended as an effective and affordable method of assessing the toxicity (Placek et al. 2016) and genotoxicity of environmental samples with a sensitivity similar to tests using mammalian cells (Obidoska et al. 2015). In this paper, coke wastewater after biological treatment in coke plant was directed to integrated membrane processes (filtration on a sand bed-reverse osmosis), and the phytotoxicity of wastewater on a test plant Vicia faba was assessted.

\section{Characteristics of Wastewater Generated in Coke Plants}

Coke production is based on high-temperature pyrolysis of coal in batteries of coke ovens (Ghose 2002). As a result of the degassing process, coke (constituting a $70-80 \%$ proportion of all the coking products) and the raw coke oven gas are obtained. The byproducts are tar, coking benzol (depending on the technology used), products of the desulphurisation of and binding of ammonia from the coke oven gas through such products as as ammonium sulphate (Martínková and Chmátal 2016).
Coke plants are facilities which consume large amounts of water and generate highly polluted wastewater from the production proces (Dong and Zhang 2010). The wastewater generated in the process of coke production and purification, and the processing of coking by-products can be divided into the following types:

- coal water (ammonia) resulting from the condensation of derived water vapour (from coke oven gas, during the cooling operation);

- outflows from the treatment by-products of degassing;

- effluent from wet coke quenching;

- liquids from the rectification and condensing of benzene;

- leachate resulting from the processing of tar and hydrogen sulphide;

- condensates of water vapour consumed for the direct heating of media in technological processes (e.g. stripping ammonia from the coal water and benzene from the wash oil);

- outflows from the closures of hydraulic gas pipes;

- condensates from the cleaning of implanted impurities from the equipment and ducts by means of water vapour;

- outflows from the periodic cleaning of floors, equipment, devices, etc. (Alexandersson 2007; BAT 2005).

Coke wastewater is a complex industrial wastewater present in most steelworks (Vázquez et al. 2007). The main factor determining the amount of wastewater generated during the process of coking coal is the amount of processed raw material. The amount of wastewater is also dependent on the type of coal used in the process of gas purification, the technologies for the recovery of byproducts and the water/wastewater management model used (Qi et al. 2007). The average quantity of process wastewater arising from the coke plant ranges from 0.15 to $0.35 \mathrm{~m}^{3} / \mathrm{Mg}$ of coal. From this, one can calculate that between 0.35 and $0.45 \mathrm{~m}^{3}$ of wastewater arises per tonne of coke produced (Bartkiewicz 2008). The basic pollutants in coke wastewater include toxic compounds such as ammonia salts $\left(\mathrm{CN}^{-}, \mathrm{SCN}^{-}\right)$, phenols, oils, tars, suspensions, polycyclic aromatic hydrocarbons (PAHs) (Włóka et al. 2017), toxic organic nitrogen compounds, cyanide (Oulego et al. 2014) ammonia and hydrogen sulphide (Smol and Włodarczyk-Makuła 2015). It is worth noting that coke wastewater is classified as an 
onerous industrial effluent. Contaminants present in the post-process coke wastewater are a source of indirect emissions of PAHs in the case of coke wastewater used to supplement the circulation of wet quenching of coke. The composition of coke wastewater from different plants is shown in Table 1. Individual concentrations of the components listed vary according to the type of coal used and the modifications made to each specific process.

According to the legal restrictions, coking enterprises are obliged to carry out coke production with the use of Best Available Techniques (BAT). In Directive 96/62/ EC on integrated pollution prevention, called the IPPC (Integrated Pollution Prevention and Control), standard BAT determines limits to emission levels for large industrial plants, including the coking plant. The characteristics of BAT in the European coke industry were concluded in a BREF document (Best Available Techniques Reference Document on the Production of Iron and Steel), Seville 2000. In accordance with BAT standards, it is essential that those available technological and technical solutions should be used which contribute to minimising the emission of pollutants into the air and soil-water environment. According to Polish law, the coke companies are required to obtain an integrated permit (Smółka et al. 2003) as the installation can be a source of significant pollution of the natural environment (Włóka et al. 2013).

Water and wastewater management in coke plants depends on the technical and technological solutions used. Wastewater discharged from large installations is subjected to a multi-step purification process, and wastewater from smaller installations, after initial pre-treatment, is returned to the technological cycle at the plant (for wet quenching of coke) or discharged into municipal sewage treatment plants. Raw coke wastewater contains the toxic compounds indicated above which are very harmful to human health, and it cannot be introduced into receivers (natural watercourses and sewers) without treatment. In most cases, wastewater is initially treated in biological treatment installations located in the area of the coking plant. However, after the biological processes, the quality of coke wastewater is often unsatisfactory (Smol et al. 2014b). Therefore, it is necessary to develop sustainable concepts for treating wastewater (Dudziak and Gryta 2013) properly in order to avoid any adverse technological, environmental and ecological impacts on the receiver (Smol et al. 2016a, b).

\section{Materials and Methods}

\subsection{Experimental procedure}

Coke wastewater samples were collected from a plant located in Silesia, southern Poland. The production capacity of the plant is $600,000 \mathrm{t}$ of coke per annum. Wastewater was treated in the treatment plant by biological processes involving the separate denitrification, nitrification and oxidation of organic carbon. A diagram showing the individual stages of coke wastewater treatment in the study plant and the location of sampling is shown in Fig. 1.

Coke wastewater after the biological treatment in the coke plant was directed to laboratory experiment. According to high effectivnes in the removal of pollutants from aquatic solutions, adsorption (Dudziak and Werle 2016) and membrane processes (Tomaszewska and Bodzek 2013a, b) were used in this study. Wastewater samples were taken from the tank and stored in 101 containers at a temperature of $10{ }^{\circ} \mathrm{C}$. Coke wastewater was filtered on a sand bed (pre-filtration) in the laboratory. The sand bed was a cylinder shaped container filled with three layers of gravel and sand. The layers were composed of bottom layer gravel $\varnothing=1.0 \mathrm{~cm}$, middle layer gravel $\varnothing=0.6 \mathrm{~cm}$ and upper layer sand $\varnothing=0.1-$ $2.0 \mathrm{~mm}$. The total depth of the filter layers was $50 \mathrm{~cm}$, and the volume of the filter bed was $25 \mathrm{~L}$. After prefiltration, wastewater was directed to the membrane module for the main filtration - a high-pressure crossflow GE-Water SEPA CF Membrane Cell (Bohdziewicz et al. 2016) with one nylon RO membrane (ADF). The setting operated in cross-flow closed system mode in which the retentate was recycled to the feed tank (Smol et al. 2016a, b). The $\mathrm{pH}$ range of the membrane operation is $1-11$ with a maximum temperature of $50^{\circ} \mathrm{C}$ and salt rejection for $\mathrm{NaCl}$ of $95.5 \%$. The filtration area was $144 \mathrm{~cm}^{2}$, the transmembrane pressure of the process remained at the value of $2.0 \mathrm{MPa}$, the linear flow velocity over the membrane surface was $2 \mathrm{~m} \cdot \mathrm{s}^{-1}$, and the permeate flux was equal to $4.59 \cdot 10^{-6} \mathrm{~m}^{3} / \mathrm{m}^{2} \cdot \mathrm{s}$.

The concentration of selected indicators in the wastewater was measured, comprising the concentration of 16 polycyclic aromatic hydrocarbons listed by the U.S. Environmental Protection Agency, $\mathrm{pH}$, temperature, total nitrogen (TN), chemical oxygen demand (COD), total organic carbon (TOC), total carbon (TC) and suspended soils (SS). Tests of indications were performed in four replicates. Coke wastewater was analysed in accordance with generally accepted 


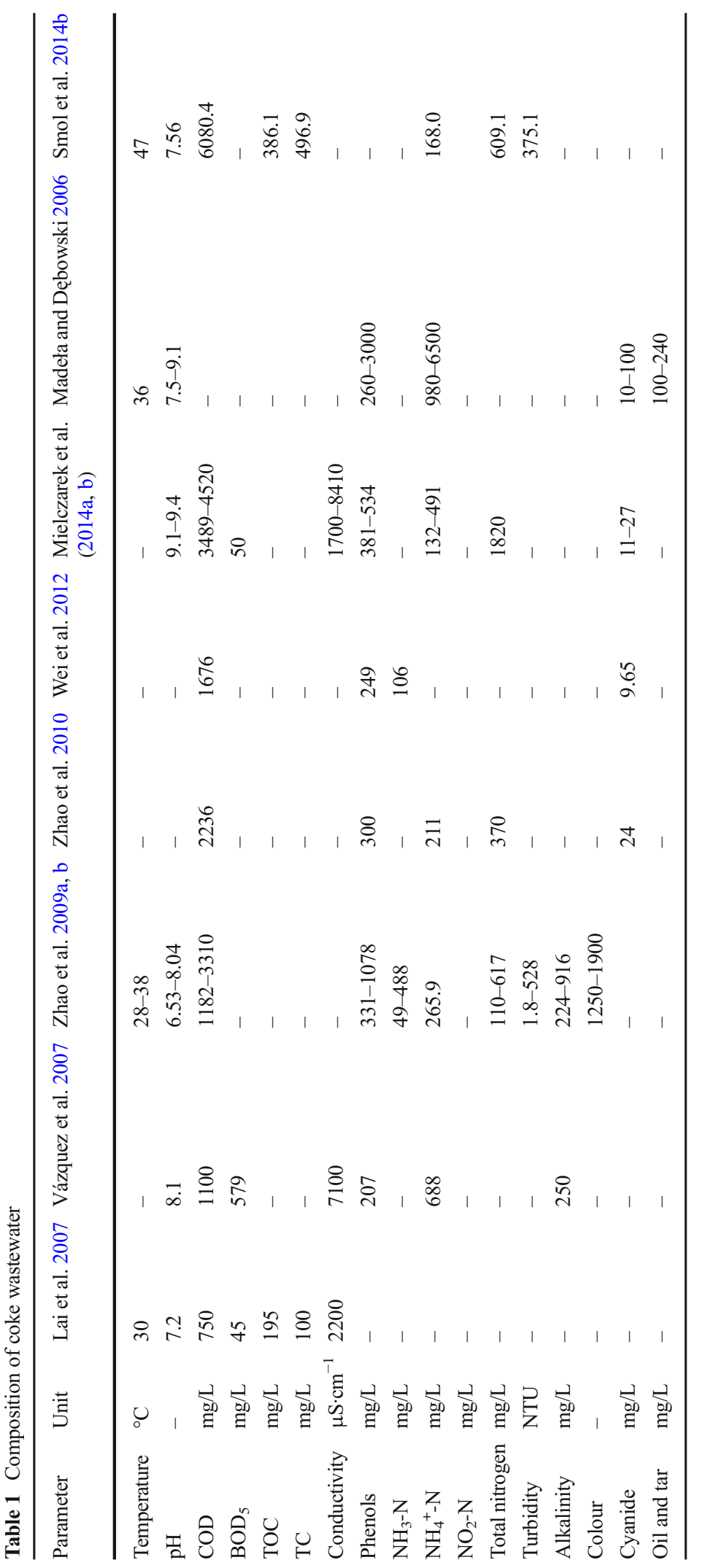




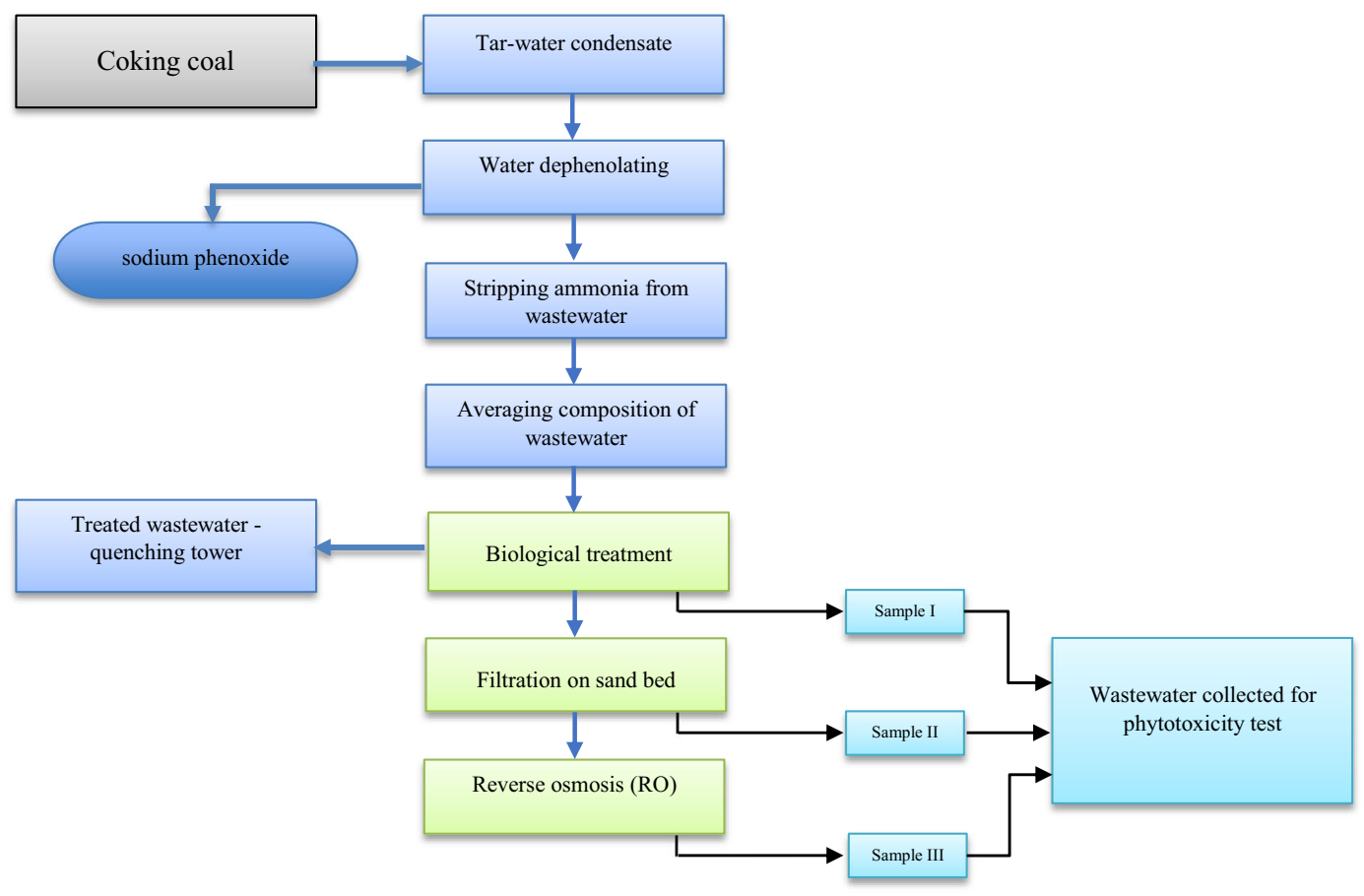

Fig. 1 Stages of coke wastewater treatment

methodologies (Dojlido et al. 1999) briefly described in Smol et al. (2017).
The standard limit values of the selected indicators defined in Polish regulations are shown in Table 2.

Table 2 The limit values of selected indicators in wastewater (Smol et al. 2014a)

\begin{tabular}{|c|c|c|c|}
\hline Indicator & Unit & $\begin{array}{l}\text { Indexes of sewage pollution which } \\
\text { is to adischarged to a natural receiver* }\end{array}$ & $\begin{array}{l}\text { Indexes of sewage pollution } \\
\text { which is directed to sewers** }\end{array}$ \\
\hline $\mathrm{pH}$ & - & $6.5-9.0$ & $6.5-9.5$ \\
\hline temperature & ${ }^{\circ} \mathrm{C}$ & 35 & 35 \\
\hline Ammonium nitrogen & $\mathrm{mg} \mathrm{N}-\mathrm{NH}_{4}{ }^{+} / \mathrm{L}$ & 10 & $100^{1)} 200^{2)}$ \\
\hline Nitrate nitrogen & $\mathrm{mg} \mathrm{NO}_{3}{ }^{-} / \mathrm{L}$ & 30 & 10 \\
\hline COD & $\mathrm{mg} \mathrm{O}_{2} / \mathrm{L}$ & 125 & 3) \\
\hline TOC & $\mathrm{mg} \mathrm{C} / \mathrm{L}$ & 30 & 3) \\
\hline $\mathrm{TC}$ & $\mathrm{mg} \mathrm{C} / \mathrm{L}$ & ns. & ns. \\
\hline SS & $\mathrm{mg} / \mathrm{L}$ & 35 & 3) \\
\hline 16PAHs & $\mu \mathrm{g} / \mathrm{L}$ & ns. & $200 * * *$ \\
\hline
\end{tabular}

ns, not standardised

*Journal of law 2014 item. 1800

**Journal of law 2006 no. 136, item. 964

*** calculated on the basis of carbon content

${ }^{1)}$ For wastewater discharged to the treatment plant for an area with a population $>5000$

${ }^{2)}$ For wastewater discharged to the treatment plant for an area with a population $\leq 5000$

${ }^{3)}$ The values of indicators should be based on the permissible load of these pollutants for individual treatment plants 


\subsubsection{Wastewater treatment methods}

The test was designed to determine the impact of coke wastewater on the germination of the test plant, broad bean (Vicia faba). The first wastewater sample was taken from the coke treatment plant: sample I-after the biological treatment. The second and third samples were prepared in the laboratory: sample II-after filtration through the sand bed, sample III-after reverse osmosis. All tests were conducted in three replicates.

\subsubsection{Wastewater samples for germination tests}

An innovative research technique, in vitro tests, was used for the study of phenomena resulting from the toxicity of pollution on plants. The toxicity test was set up in the large scale phytothrone chamber BioGenet. The prepared experiment was hold, with use of four experimental blocks. Each block includes two sets of Petri plates with two types of incubation matrix. Plates in first block was filed only with the incubation matrix (control sample). Wastewater was added to the remaining blocks, according to the instructions outlined in the previous paragraph (sample I; sample II; sample III).

\subsubsection{Preparation of Seeds for the Test}

Tests were performed on selected (without blemish, of similar size) seeds of the test plant-Vicia faba. All seeds came from one producer and from the same series. Initially, the seeds were stored at $4{ }^{\circ} \mathrm{C}$ for $24 \mathrm{~h}$. Then, the seeds were sterilised in a mixture of ethyl alcohol $96 \%$ and hydrogen peroxide 34\% (1:1) for $7 \mathrm{~min}$, washed ten times in $200 \mathrm{ml}$ of sterile distilled water and further placed by sterile tweezers (well heated above a flame) into sterile Petri dishes with a cotton matrix and sterile Petri dishes with a prepared matrix of Murashige and Skoog Basal Medium (MSBM). In each variant, 50 seeds were placed on the plate, (three repetitions). All operations were performed in a chamber with laminar air flow.

\subsubsection{Germination Conditions}

Seed germination was carried out for $72 \mathrm{~h}$ under controlled conditions in the phytothrone chamber, at a temperature of $21{ }^{\circ} \mathrm{C}$ (day) and $18{ }^{\circ} \mathrm{C}$ (night). Plants were grown under artificial illumination (fluorescent lamps) in an all day cycle. After the incubation period, both seeds that had germinated and those that had not germinated were counted.

\subsubsection{Statistical Analysis}

The membrane process capacity was enabled by the determination of volumetric permeate flux for deionised water $-J_{\mathrm{w}}$ and simulated solutions $J_{\mathrm{v}}$ calculated based on formula incicated in Bohdziewicz et al. 2014. The efficiency of the filtration was determined on the basis of the retention ratio [\%]. For the membrane techniques, retention coefficient $[R, \%]$ is used (Smol and Włodarczyk-Makuła 2017).

Average values for the germinating seeds were calculated for each sample, based on a control sample. The toxicity indicator, inhibition of germination (inhibition), was determined according to the following formula:

$I=\frac{A-B}{A} \cdot$ inhibition $=100[\%]$

where:

I inhibition of germination (inhibition) [\%],

A seed germination in the control sample,

B seed germination in a test sample (TrojanowskaOlichwer 2013).

In order to evaluate a statistical valid differences between samples, the one-way ANOVA test, followed by Tukey's post hoc range analysis, was performed. This procedure was conducted on StratSoft STATISTICA software.

\section{Results and Disscusion}

\subsection{The Removal Efficiency of Selected Pollution} from Coke Wastewater

The composition of the raw and treated coke wastewater is shown in Table 3.

In many cases, coking wastewater contains high concentration of refractory and toxic compounds and water quality usually cannot meet the discharge standards after conventional biological treatment. According to legal regulations (Journal of law 2014, item. 1800), the wastewater treated in the biological wastewater plant did not meet the quality standards since the concentrations of some selected indicators were too high-COD, TOC. 
Table 3 Changes in the physical and chemical indicators of coke wastewater after the treatment processes

\begin{tabular}{|c|c|c|c|c|c|}
\hline \multirow[t]{2}{*}{ Indicator [unit] } & \multirow{2}{*}{$\begin{array}{l}\text { Biological treatment } \\
\text { Value }\end{array}$} & \multicolumn{2}{|c|}{ Filtration on sand bed } & \multicolumn{2}{|c|}{ Reverse osmosis (RO) } \\
\hline & & Value & Retention ratio [\%] & Value & Retention coeeficient ${ }^{*}, R[\%]$ \\
\hline $\mathrm{pH}$ & 7.2 & 7.9 & - & 7.4 & - \\
\hline $\mathrm{COD}\left[\mathrm{mg} \mathrm{O}_{2} / \mathrm{L}\right]$ & 6067.4 & 3692.1 & 39.1 & 567.3 & 84.6 \\
\hline $\mathrm{TN}\left[\mathrm{mg} \mathrm{NH}{ }_{4}^{+} / \mathrm{L}\right]$ & 334.5 & 180.2 & 46.1 & 9.1 & 94.9 \\
\hline TOC $[\mathrm{mg} \mathrm{C} / \mathrm{L}]$ & 411.1 & 238.3 & 42.0 & 35.2 & 85.2 \\
\hline $\mathrm{TC}[\mathrm{mg} \mathrm{C} / \mathrm{L}]$ & 717.5 & 382.9 & 46.6 & 54.1 & 85.9 \\
\hline $\mathrm{SS}[\mathrm{mg} / \mathrm{L}]$ & 132.6 & 67.0 & 49.5 & 1.1 & 98.4 \\
\hline 16PAHs $[\mu \mathrm{g} / \mathrm{L}]$ & 94.73 & 45.2 & 53.3 & 15.04 & 67.0 \\
\hline
\end{tabular}

* Retention coefficient was calculated for wastewater taken after filtration on sand bed, and treated in RO process

In this study, a range of $\mathrm{pH}$ between 5.2 and 7.9 was selected. The $\mathrm{pH}$ of the wastewater after filtration on sand bed was equal to 7.9. During the reverse osmosis, the value of $\mathrm{pH}$ decreased to 7.4. In accordane to the polish legalisation, the value of $\mathrm{pH}$ did not exceed the permissible values of 6.5-9.0 in the treated wastewater collected to the natural reservoir (Journal of law 2014 item.1800) and the permissible values of 6.5-9.5 in the treated wastewater collected to the severs (Journal of law 2006 no. 136, item. 964). This value of $\mathrm{pH}$ is also in the range characteristic for coking wastewater, given by Bartkiewicz (2006).

The value of COD was equal to $6067.4 \mathrm{O}_{2} / \mathrm{L}$ and decreased to $3692.1 \mathrm{mg} \mathrm{O}_{2} / \mathrm{L}$ after filtration on sand bed and to $567.3 \mathrm{mg} \mathrm{O}_{2} / \mathrm{L}$ after RO. The effectiveness in the removal of the initial COD was $39.1 \%$ for filtration on sand bed and $84.6 \%$ for reverse osmosis. The final concentration of COD still exceeded the permissible values of treated wastewater. In Zhang et al. (1998) work, removal efficiencies of COD from coking wastewater in anaerobic-anoxic-oxic $\left(\mathrm{A}_{\mathrm{I}}-\mathrm{A}_{2}-\mathrm{O}\right)$ fixed biofilm system was equal to $98.8 \%$.

The total nitrogen concentration in wastewater from plant reached $334.5 \mathrm{mg} \mathrm{NH}_{4}+\mathrm{L}$. The filtration on sand bed removed approximately $46.1 \%$ of $\mathrm{TN}$ to value of $180.2 \mathrm{mg} \mathrm{NH}_{4}+/ \mathrm{L}$. The total nitrogen removal efficiency during reverse osmosis was equal to $94.9 \%(9.1 \mathrm{mg}$ $\mathrm{NH}_{4}+/ \mathrm{L}$ ).

Following the treatment processes, it showed a decrease of TOC concentration from 411.1 after biological treatment, to $238.3 \mathrm{mg} \mathrm{C} / \mathrm{L}$ after filtration on sand bed (Removal degree $=42.0 \%$ ) and to $35.2 \mathrm{mg} \mathrm{C} / \mathrm{L}$ after RO (Retention coeeficient $=85.2 \%$ ). TOC removal in RO was similar like in previous study $-85.9 \%$ (Smol et al. 2014b). The concentration of TC declined after the processes. The effectiveness in TC removal during filtration on sand bed was equal to $46.6 \%$ (382.9 $\mathrm{mg} \mathrm{C} / \mathrm{L}$ ) and $85.9 \%$ after reverse osmosis $(54.1 \mathrm{mg} \mathrm{C} / \mathrm{L})$.

The concentration of SS reached $132.6 \mathrm{mg} / \mathrm{L}$ in bilogically treated wastewater. The $49.5 \%$ removal of suspended soils was achieved using after filtration on sand bed $(67 \mathrm{mg} / \mathrm{L})$. The concentration of SS declined by $98.4 \%$ after RO to $1.1 \mathrm{mg} / \mathrm{L}$.

The initial concentrations of PAHs in the coke wastewater from plant were equal to $94.73 \mu \mathrm{g} / \mathrm{L}$ (Table 5). After the filtration on sand bed, the concentrations of the studied hydrocarbons gradually lowered by $52.3 \%$ to the value $45.2 \mu \mathrm{g} / \mathrm{L}$ and after reverse osmosis to value of $5.57 \mu \mathrm{g} / \mathrm{L}($ Retention coeeficient $=87.7 \%)$. In previous studies, the efficiency in 16 EPA PAHs removal from coke wastewater after RO was $89.9 \%$ (Smol et al. 2014b) (Table 4).

The efficiency in removal of individual hydrocarbons was in the 19-100\% range (Fig. 2). The average value of the retention coefficient for integrated system filtrationRO was equal to $94.1 \%$. In studies of other authors, the efficiency in removal of PAHs from water in RO reached $88.4 \%$ (Bodzek and Konieczny 2011).

The obtained findings indicated that wastewater additionally treated in the process of reverse osmosis still did not meet the standards of quality since the concentration of COD and TOC was high. However, treated wastewater can be converted back and used as technical water in the coke plant, in accordance with a 'zero waste' strategy. A zero waste strategy is one of the most visionary concepts (COM 2014, 398) for solving waste problems and assumes that one is moving towards a more circular economy (CE). Transition to a more 
Table 4 Concentration and percentage share of PAHs in coke wastewater treated in biological process, filtration on sand bed and reverse osmosis

\begin{tabular}{|c|c|c|c|c|c|c|}
\hline \multirow[t]{2}{*}{ PAHs } & \multicolumn{2}{|c|}{ Biological treatment } & \multicolumn{2}{|c|}{ Filtration on sand bed } & \multicolumn{2}{|c|}{ Reverse osmosis (RO) } \\
\hline & {$[\mathrm{ng} / \mathrm{L}]$} & {$[\%]$} & {$[\mathrm{ng} / \mathrm{L}]$} & {$[\%]$} & {$[\mathrm{ng} / \mathrm{L}]$} & {$[\%]$} \\
\hline Naf & $23,905.59$ & $25.2 \pm 4.2$ & 9769.9 & $21.6 \pm 7.1$ & 2911.48 & $52.3 \pm 5.8$ \\
\hline Acyl & 115.93 & $0.1 \pm 0.1$ & 78.77 & $0.2 \pm 0.1$ & 16.71 & $0.3 \pm 0.1$ \\
\hline Ac & 7500.43 & $7.9 \pm 2.1$ & 3498.7 & $7.7 \pm 1.0$ & 490.99 & $8.8 \pm 0.9$ \\
\hline $\mathrm{Fl}$ & 302.53 & $0.3 \pm 0.1$ & 245,09 & $0.5 \pm 0.1$ & 76.17 & $1.4 \pm 0.4$ \\
\hline Fen & 107.99 & $0.1 \pm 0.1$ & 67.22 & $0.1 \pm 0.1$ & 28.21 & $0.5 \pm 0.3$ \\
\hline Ant & 220.83 & $0.2 \pm 0.1$ & 81 & $0.2 \pm 0.2$ & 9.99 & $0.2 \pm 0.2$ \\
\hline Flu & 564.34 & $0.6 \pm 0.3$ & 333.91 & $0.7 \pm 0.2$ & 63.45 & $1.1 \pm 0.9$ \\
\hline Pir & 899.42 & $0.9 \pm 0.2$ & 521.01 & $1.2 \pm 0.3$ & 92.1 & $1.7 \pm 0.1$ \\
\hline $\mathrm{BaA}$ & $13,897.67$ & 14.73 .2 & 9032.1 & $20.0 \pm 1.3$ & 762.09 & $13.7 \pm 1.9$ \\
\hline $\mathrm{Chr}$ & 9090.99 & $9.6 \pm 0.8$ & 6721.06 & $14.9 \pm 2.1$ & 859.3 & $15.4 \pm 2.2$ \\
\hline $\mathrm{BaP}$ & 5891.4 & $6.2 \pm 0.5$ & 2981.2 & $6.6 \pm 0.5$ & 67.31 & $1.2 \pm 0.1$ \\
\hline $\mathrm{BbF}$ & 1453.94 & $1.5 \pm 1.0$ & 672.11 & $1.5 \pm 0.3$ & 90.32 & $1.6 \pm 0.9$ \\
\hline $\mathrm{BkF}$ & $24,098.55$ & $25.4 \pm 2.4$ & 9091.35 & $20.1 \pm 2.2$ & 96.02 & $1.7 \pm 0.4$ \\
\hline DahA & 3536.98 & $3.7 \pm 0.4$ & 1018.21 & $2.3 \pm 0.9$ & 2.21 & 0.0 \\
\hline IP & 2190.01 & $2.3 \pm 1.1$ & 645.91 & $1.4 \pm 0.2$ & 0.1 & 0.0 \\
\hline BghiP & 953.47 & $1.0 \pm 0.1$ & 453.07 & $1.0 \pm 0.3$ & 5.32 & $0.1 \pm 0.1$ \\
\hline$\sum$ & $94,730.07$ & - & $45,210.61$ & - & 5571.77 & - \\
\hline
\end{tabular}

circular economy requires many changes throughout the value chains, including new ways of turning wastewater into a resource (COM 2015, 614). This implies systemic change, and innovation not only in technologies, but also in the organisation, society, finance methods and policies (Kulczycka and Smol 2016). In industrial networks, zero waste can be understood as a new standard for efficiency and integration (Curran and Williams 2012). A significant improvement in environmental protection is required through the use of the highly effective methods of industrial wastewater treatment that meet the standards and requirements of Polish (Turek et al. 2016) and EU environmental law, defined by the IPPC Directive.

\subsection{Phytotoxicity Assessment of Coke Wastewater}

To evaluate wastewater toxicity, tests were performed with the test plant Vicia faba. The parameters shown in Table 5 (the basic characteristics of the germination inhibition and the degree of toxicity) were used.

Results obtained from the first experimental block (control sample) show that the germination index, in the case of seeds incubated in cotton matrix was $81.3 \pm 3.5$, while the germination index for seed incubated in MSBM was $96.7 \% \pm 1.5$.

The phytotoxity of the treated wastewater was evaluated during this investigation. The effects of the coke wastewater (concentration $100 \%, 50 \%, 25 \%$ ) on the inhibition of seed germination of the test plant Vicia faba are shown in Figs. 2 and 3 (samples I, II and III). The test results for the cotton matrix are shown in Fig. 3 and for Murashige and Skoog Basal Medium are shown in Fig. 4.

The results of the one-way ANOVA test are presented in Table 6. This analysis was conducted individually on the groups of sampes I, II and III, for both used incubation matrix.

The inhibition of germination (\%) of Vicia faba in sample I-wastewater (concentration 100\%) collected from the biological treatment plant was in the range of 90-98\% for a cotton matrix and $92-100 \%$ for the Murashige and Skoog Basal Medium matrix. These results confirmed that coke wastewater was insufficiently treated following the biological process and was strongly toxic to the test plant - the degree of toxicity was 3. The germination inhibition for the diluted wastewater (concentration 50\%) was in the range of 72-78\% 


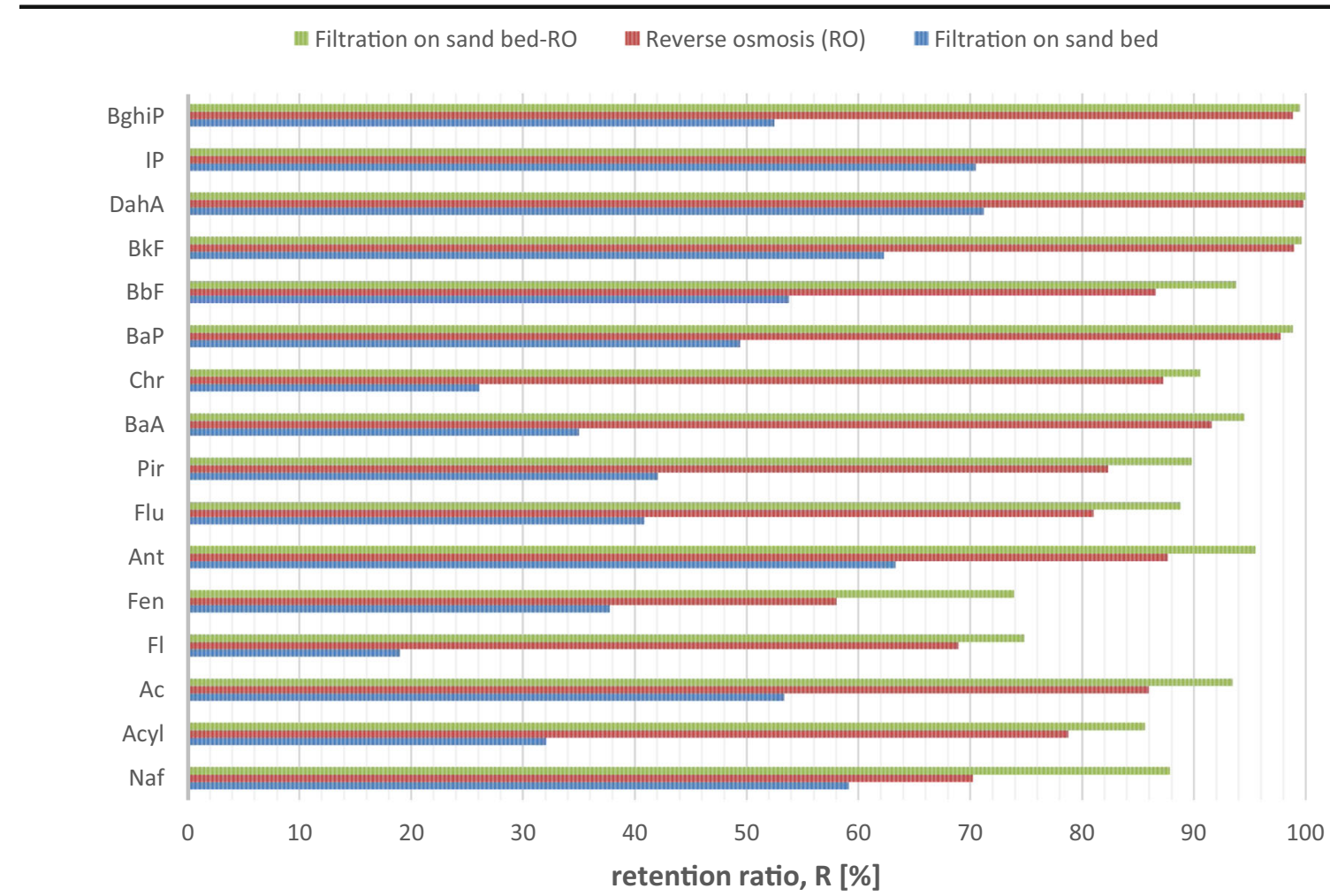

Fig. 2 PAHs removal efficiency in treatment processes

for the cotton matrix and $84-90 \%$ for the MSBM matrix. These samples are strongly toxic, the degree of toxicity is 3 . For a concentration of $25 \%$, the germination inhibition was still in the range for strongly toxic wastewater (degree of toxicity 3 ) and was equal to $66 \%$ for the cotton matrix and $82 \%$ for the MSBM matrix.

The germination inhibition of the test plants in sample II-wastewater filtered on a sand bed (concentration $100 \%$ ) was equal to $48 \%$ for the cotton matrix and $54 \%$ for the commercial MSBM matrix. The germination inhibition decreased on dilution of the sample. The germination inhibition for the diluted wastewater (concentration 50\%) was equal to $42 \%$ for the cotton and MSBM matrices. The germination inhibition for the $25 \%$ concentration of wastewater was in the range of

Table 5 The degree of toxicity (Adamcová et al. 2016)

\begin{tabular}{lll}
\hline $\begin{array}{l}\text { Inhibition } \\
{[\%]}\end{array}$ & The degree of toxicity & Evaluation \\
\hline $\mathrm{I}^{*}<10$ & 1 & Non-toxic or slightly toxic \\
$10<I<50$ & 2 & Toxic \\
$50<\mathrm{U}$ & 3 & Highly toxic \\
\hline
\end{tabular}

24-38\% for cotton and $14-36 \%$ for the MSBM matrix. The results confirmed that wastewater, even after treatment on a sand bed, was still toxic with a degree of toxicity of 2 .

In the last phase of the research, wastewater treated in reverse osmosis was examined. The germination inhibition of Vicia faba for sample III (concentration 100\%) was in the range of $6-10 \%$ for cotton and $4-12 \%$ for the MSBM matrix. Sample III was diluted to $50 \%$ concentration. This contributed to a decrease in the germination inhibition value. The germination inhibition was in the range of $4-6 \%$ for the cotton matrix and $2-6 \%$ for the MSBM matrix. These samples are non-toxic or slightly toxic for the test plant, the degree of toxicity is 1 .

The results presented in Table 4 indicate that all analysed samples show a statistically valid differences between the level of germination inhibition, within groups. The large differences can be observed in samples with the addition of wastewater treated in the biological processes. This result may mean that phytotoxicity of wastewater not treated by filtration techniques is highly dependent on the dose of this waste. This conclusion is also confirmed by post hoc Tukey's test. This additional analysis, of individual differences between 


\section{3th replicate II 2 nd replicate II 1st replicate}

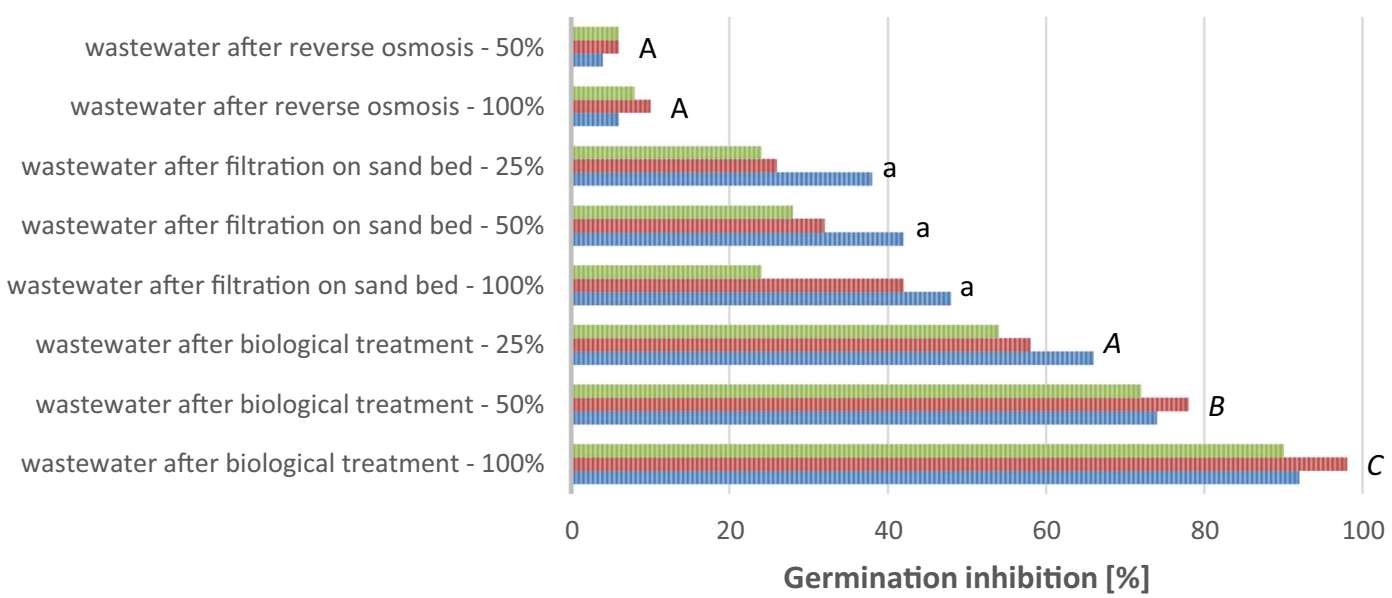

Fig. 3 Germination inhibition of Vicia faba (cotton matrix)

single means, within groups of samples, shows that only in case of samples with the addition of wastewater after biological treatment the statistical valid differences can be observed.

Based on the tests conducted, significant, linearly increasing toxicity of coke wastewater was indicated. In all series, correlation is observed between an increasing concentration of wastewater and the inhibition of growth of the test plant. Such a relationship has also been demonstrated by other authors. In the work of Adamcová et al. (2016), the plant species of the Phytotoxkit microbiotest responded differently to the degree of contamination of the sewage sludge samples with a concentration $100,50,25$ and $10 \%$. Growth inhibition values clearly revealed the inhibitory effects of sewage sludge contaminants on seed germination and root elongation of Sinapis alba L. (Adamcová et al. 2016).

The present study highlights the need to monitor not only the basic physical and chemical indicators (including the level of toxic substances such as PAHs), but also their effect on test organisms. Despite the fact that wastewater was treated in a biological installation, it still contains substances strongly hazardous to health and life - the degree of toxicity reached 3 . After filtration on a sand bed, the reduction of selected indicators was equal to $39 \%$ for COD, $46 \%$ for TN, $42 \%$ for TOC, $47 \%$ for TC, $50 \%$ for SS and $53 \%$ for toxic PAHs. However, wastewater still showed a toxic effect- the degree of toxicity reached 2 . Reverse osmomis was the most effective process in the removal of the indicators

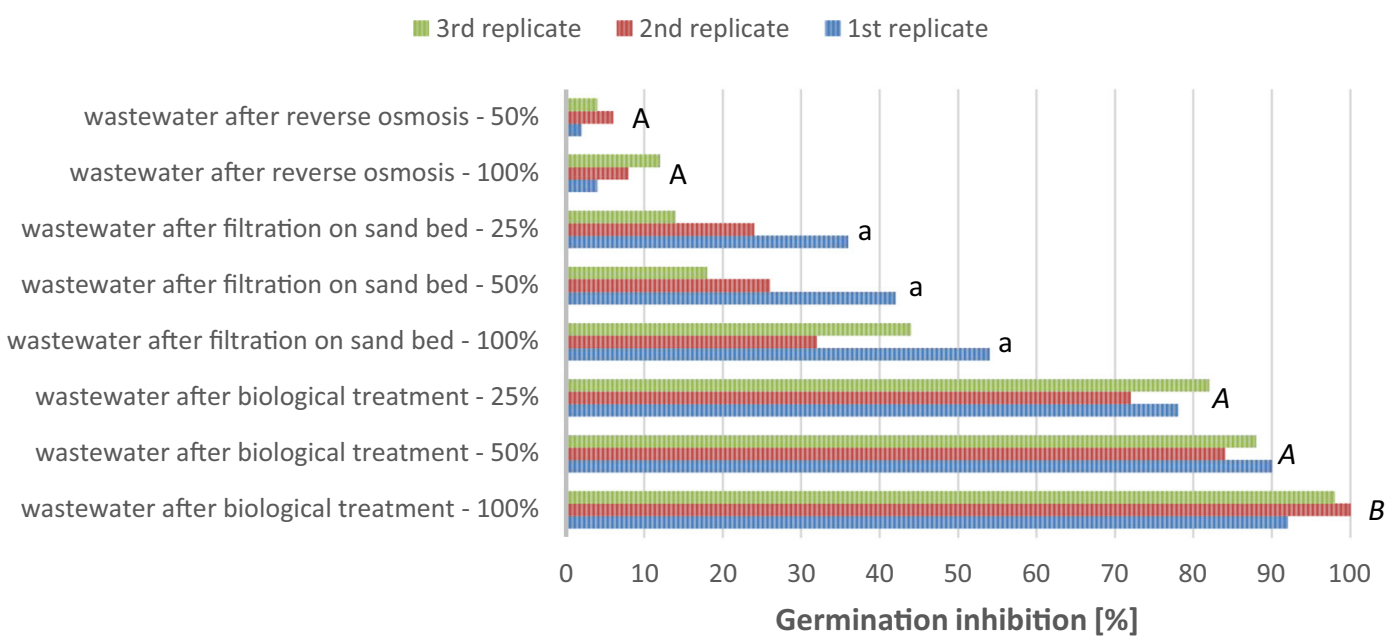

Fig. 4 Germination inhibition of Vicia faba (Murashige and Skoog Basal Medium matrix) 
analysed. The concentration of COD decreased by $85 \%$, $\mathrm{TN}-95 \%$, TOC $-85 \%$, TC $-85 \%$, SS $-98 \%$ and sum of $16 \mathrm{PAHs}-67 \%$.

The effect of wastewater and sludge on seed germination and plant growth has been the subject of research of numerous researchers (Adamcová et al. 2016). The assessment of the genotoxicity of coke wastewater was studied by Sindera et al. (2011). The authors indicated that despite the fact that a reduction of TOC and COD of about $90 \%$ was noted in the treated coke wastewater, it still contains substances toxic to health and life. The paper presents the results of tests of raw and biologically treated wastewater for its phyto- and genotoxicity for Vicia faba. It was observed that with an increasing concentration of wastewater, germination inhibition also increases. The germination inhibition was in the range of $65-79 \%$ for a $30 \%$ concentration of treated wastewater and $70-80 \%$ for a $60 \%$ concentration. Raw coke wastewater showed a significantly greater effect on the test plant as compared with the samples obtained from the effluent. The growth inhibition was equal to $89 \%$ (Sindera et al. 2011). In the research of Khoufi et al. (2006), an integrated technology for the treatment of the recalcitrant contaminants of olive mill wastewater was examined. The method involves an electrochemical step for the pre-treatment of wastewater using the electro-Fenton reaction followed by an anaerobic bio-treatment. The authors indicated that the electroFenton process removed $65.8 \%$ of the total polyphenolic compounds and subsequently decreased the wastewater toxicity from 100 to $66.9 \%$, which resulted in improving the performance of the anaerobic digestion. In the combined process, a high overall reduction in COD, suspended solids, polyphenols and lipid content was achieved by the two successive stages. The authors emphasise that the result opens promising perspectives since its use in the process concept as a fast and cheap pretreatment prior to conventional anaerobic post-treatment through electro-coagulation as post-treatment technology completely detoxified the anaerobic effluent and removed its toxic compounds (Khoufi et al. 2006). The genotoxicity of coking wastewater was studied using Vicia faba and Hordeum vulgare root tip cytogenetic bioassays by Dong and Zhang (2010). Results showed that the coke wastewater decreased the mitotic index, and significantly enhanced the frequencies of micronucleus, sister chromatid exchange and pycnotic cell in concentration-dependent manners. Exposure to the same wastewater concentration, the increasing ratios of above genetic injuries were higher in Vicia faba than that in Hordeum vulgare (Dong and Zhang 2010). Vicia faba is more sensitive for toxic environment and should be used in toxity tests. The toxicity of coke wastewater treated with advanced oxidation by the Fenton process supported by an ultrasonic field was studied by KwarciakKozłowska and Krzywicka (2016). Two doses of iron ( $4 \mathrm{~g} / \mathrm{L}$ and $40 \mathrm{~g} / \mathrm{L}$ ) and four doses of hydrogen peroxide (an amount proportional to the value of the COD of raw wastewater, ranging from a $\mathrm{COD} / \mathrm{H}_{2} \mathrm{O}_{2}$ ratio of $1: 2.5$ to 1:20) were used. Two tests, an algal growth inhibition test and a Lepidium sativum test, were used to determine the toxicity of coke wastewater. The authors indicated that higher COD and TOC value reductions were obtained after application of a higher dose of ferrous sulphate ( $40 \mathrm{~g} /$ L). Higher toxicity to Lepidium sativum was observed when a higher dose of ferrous sulphate and the lowest dose of hydrogen peroxide were introduced to wastewater samples. On the other side, higher toxicity to algae was observed for a lower dose of ferrous sulphate. In this case, increasing the dose of hydrogen peroxide resulted in a decrease in toxicity (Kwarciak-Kozłowska and Krzywicka 2016). Phytotoxicity tests are also used in order to check the effectivness of phytoremediation as an in situ method. Al-Baldawi et al. (2013) conducted phytotoxicity tests on Scirpus grossus on contaminated water at different diesel concentrations $(0,8700,17,400$ and $26,100 \mathrm{mg} / \mathrm{L})$. The percentage degradation of total petroleum hydrocarbons (TPH) by the test plant was recorded from the extraction of synthetic wastewater with plants and the corresponding control contaminant without plants during the 72-day treatment period. After this

Table 6 Results of one-way ANOVA test

\begin{tabular}{llll}
\hline & \multicolumn{2}{l}{ One-way ANOVA $p$ value } & \\
\cline { 2 - 4 } & Biological treatment & Filtration on sand bed & Reverse osmosis \\
\hline Cotton matrix & $3.2210^{-4}$ & 0.56 & 0.12 \\
MSBM matrix & $3.3810^{-3}$ & 0.19 & 0.20 \\
\hline
\end{tabular}


period of wastewater treatment in a subsurface flow system, authors indicated that $S$. grossus has the capability to survive and provide good conditions for rhizobacteria to degrade hydrocarbon at all the diesel concentrations investigated (Al-Baldawi et al. 2013). In the current paper, evaluation of toxicity of coke wastewater was carried out for the plant organisms, but the analysis can also be expanded taking into account other organisms, e.g. fish and animals. Zhou et al. (2015) conducted a battery of toxicity tests using photo bacterium, algae, crustacean and fish to evaluate acute toxicity profile of coking wastewater after the novel wastewater treatment process - vertical tubular biological reactor (VTBR). Authors indicated decrease in toxicity of coking wastewater after VTBR: Toxicity Unit (TU) decreased from 21.2 to 0.4 for Photobacterium phosphoreum, from 9.5 to 0.6 for Isochrysis galbana, from 31.9 to 1.3 for Daphnia magna, and from 30.0 to nearly 0 for Danio rerio. A battery of toxicity tests are mentioned as useful tool for the clarity of toxicity profile for complex environmental samples (including coke wastewater) using different aquatic test organisms as photo bacterium, algae, crustacean and fish (Zhou et al. 2015). Further study should be conducted in this area.

\section{Conclusions}

The purpose of the research was to monitor the effectivnes in the removal of selected pollutants from coke wastewater in the integrated membrane processes and to determine the impact of coke wastewater on the germination of the test plant, broad bean (Vicia faba), on two matrices: cotton and Murashige and Skoog Basal Medium-MSBM. The results confirm that coke wastewater is effectively treated in presented system: filtration on sand bed-reverse osmosis, and there is a noticeable correlation between increasing concentrations of wastewater and the seed germination of the test plant.

During the investigation, a high removal efficiency was obtained for the selected indicators: after filtration through a sand bed the reduction of COD was $39 \%$, $\mathrm{TN}-46 \%, \mathrm{TOC}-42 \%, \mathrm{TC}-47 \%, \mathrm{SS}-50 \%$, $16 \mathrm{PAHs}-53 \%$ and after RO: reduction of COD$85 \%, \mathrm{TN}-95 \%$, TOC $-85 \%$, TC $-85 \%$, SS $-98 \%$, $16 \mathrm{PAHs}-67 \%$. However, there is a necessity to not only monitor the basic physical and chemical indicators, but also their effect on the test organisms.
Coke wastewater collected from the biological treatment plant showed very high levels of germination inhibition (90-98\% for the cotton matrix and 92$100 \%$ for the MSBM matrix). These samples are indicated as strongly toxic with a degree of toxicity of 3 .

Wastewater, even after treatment on a sand bed, was still toxic. Its germination inhibition was in the range of $24-48 \%$ for a cotton matrix and $14-54 \%$ for an MSBM matrix, and the degree of toxicity was equal to 2 .

The toxicity of wastewater was lowest when it was treated in a reverse osmosis process. The germination inhibition was in the range of $4-10 \%$ for a cotton matrix and $2-12 \%$ for an MSBM matrix. Wastewater after RO is non-toxic or slightly toxic to the test plant, the degree of toxicity does not exceed 1 .

Biologically treated wastewater showed significantly greater phytotoxic effects compared with those obtained in the effluent treated on a sand bed and in reverse osmosis.

Acknowledgements This research was supported by statutory research of MEERI PAS and project no. BS/BP-402-301/11 in Częstochowa University of Technology.

Open Access This article is distributed under the terms of the Creative Commons Attribution 4.0 International License (http:// creativecommons.org/licenses/by/4.0/), which permits unrestricted use, distribution, and reproduction in any medium, provided you give appropriate credit to the original author(s) and the source, provide a link to the Creative Commons license, and indicate if changes were made.

\section{References}

Adamcová, D., Vaverková, M. D., \& Břoušková, E. (2016). The toxicity of two types of sewage sludge from wastewater treatment plant for plants. Journal of Ecological Engineering, 17(2), 33-37.

Alexandersson G. 2007. Treatment of Waste Water from Coke Production. Industrial Ecology. Stockholm.

Al-Baldawi, I. A., Abdullah, S. R. S., Anuar, N., \& Idris, M. (2013). Phytotoxicity test of Scirpus grossus on dieselcontaminated water using a subsurface flow system. Ecological Engineering, 54, 49-56.

Bartkiewicz B. (2008). Treatment of industrial wastewater, PWN, Warsaw.

Best Available Techniques (BAT) - Guidelines for the coking industry. 2005. Ministry of the Environment. Warsaw.

Bartkiewicz, B. (2006). Industrial wastewater treatment. Warszawa: Polish Scientific Publishers (in Polish).

Bodzek, M., \& Dudziak, M. (2006). Elimination of steroidal sex hormones by conventional water treatment and membrane processes. Desalination, 198(1), 24-32. 
Bodzek, M., \& Konieczny, K. (2011). Membrane techniques in the removal of inorganic anionic micropollutants from water environment - state of the art. Archives of Environmental Protection, 37(2), 15-22.

Bohdziewicz, J., Kudlek, E., \& Dudziak, M. (2014). Removal of selected pharmaceutical compounds from the simulated municipal secondary effluent using the nanofiltration process. In M. Bodzek \& J. Pelczar (Eds.), Membranes and Membrane Processes in Environmental Protection, red (Vol. 119, pp. 219-228). Warsaw-Gliwice: Monographs of the Environmental Engineering Committee Polish Academy of Sciences.

Bohdziewicz, J., Kudlek, E., \& Dudziak, M. (2016). Influence of the catalyst type $\left(\mathrm{TiO}_{2}\right.$ ? and $\left.\mathrm{ZnO}\right)$ on the photocatalytic oxidation of pharmaceuticals in the aquatic environment. Desalination and Water Treatment, 57(3), 1552-1563.

Commission of European Communities. Communication no. 398, 2014. Towards a circular economy: A zero waste programme for Europe. (COM 2014, 398).

Commission of European Communities. Communication no. 614, 2015. Closing the loop — an EU action plan for the circular economy. (COM 2015, 614).

Curran, T., \& Williams, I. D. (2012). A zero waste vision for industrial networks in Europe. Journal of Hazardous Materials, 207, 3-7.

da Costa Filho, B. M., da Silva, V. M., de Oliveira Silva, J., da Hora Machado, A. E., \& Trovó, A. G. (2016). Coupling coagulation, flocculation and decantation with photo-Fenton process for treatment of industrial wastewater containing fipronil: biodegradability and toxicity assessment. Journal of Environmental Management, 174, 71-78.

Dojlido J., Dożańska W., Hermanowicz W., Koziorowski B., Zerbe J. (1999). Physical - chemical study of water and wastewater. Arkady. Warsaw.

Dong, Y., \& Zhang, J. (2010). Testing the genotoxicity of coking wastewater using Vicia faba and Hordeum vulgare bioassays. Ecotoxicology and Environmental Safety, 73(5), 944-948.

Dudziak, M., \& Gryta, M. (2013). Nanofiltration of fermentation solutions-unfavourable phenomena and membrane cleaning. Ecological Chemistry and Engineering A, 20(11), 12851294.

Dudziak, M., \& Werle, S. (2016). Studies on the adsorption of phenol on dried sewage sludge and solid gasification by-products. Desalination and Water Treatment, 57(3), 1067-1074.

Generowicz, A., Kulczycka, J., Kowalski, Z., \& Banach, M. (2011). Assessment of waste management technology using BATNEEC options, technology quality method and multicriteria analysis. Journal of Environmental Management, 92(4), 1314-1320.

Ghose, M. K. (2002). Complete physico-chemical treatment for coke plant effluents. Water Research, 36(5), 1127-1134.

Kamińska, G., Dudziak, M., Bohdziewicz, J., \& Kudlek, E. (2016). Effectivness of removal of selected biologically active micropollutants in nanofiltration. Ecological Chemistry and Engineering A, 23(2), 185-198.

Khoufi, S., Aloui, F., \& Sayadi, S. (2006). Treatment of olive oil mill wastewater by combined process electro-Fenton reaction and anaerobic digestion. Water Research, 40(10), 20072016.

Kulczycka, J., \& Smol, M. (2016). Environmentally friendly pathways for the evaluation of investment projects using life cycle assessment (LCA) and life cycle cost analysis (LCCA). Clean Technologies and Environmental Policy, 18(3), 829842.

Kwarciak-Kozłowska, A., \& Krzywicka, A. (2016). Toxicity of coke wastewater treated with advanced oxidation by Fenton process supported by ultrasonic field. Environmental Protection and Natural Resources Ochrona Środowiska $i$ Zasobów Naturalnych, 27(1), 42-47.

Lai, P., Zhao, H. Z., Wang, C., \& Ni, J. R. (2007). Advanced treatment of coking wastewater by coagulation and zerovalent iron processes. Journal of Hazardous Materials, 147(1), 232-239.

Macherzyński, B., Włodarczyk-Makuła, M., \& Nowacka, A. (2014). Desorption of PAHs from solid phase into liquid phase during co-fermentation of municipal and coke sewage sludge. Desalination and Water Treatment, 52(19-21), 3859-3870.

Madeła, M., Dębowski, Z. (2006). Sorpcja fenolu ze ścieków koksowniczych na granulowanych węglach aktywnych. Węgiel aktywny w ochronie środowiska i przemyśle (pp. 145-151).

Martínková, L., \& Chmátal, M. (2016). The integration of cyanide hydratase and tyrosinase catalysts enables effective degradation of cyanide and phenol in coking wastewaters. Water Research, 102, 90-95.

Mielczarek, K., Bohdziewiczcz, J., Włodarczyk-Makuła, M., \& Smol, M. (2014a). Modeling performance of commercial membranes in the low-pressure filtration coking wastewater treatment based on mathematical filtration models. Desalination and Water Treatment, 52(19-21), 3743-3752.

Mielczarek, K., Bohdziewiczcz, J., Włodarczyk-Makuła, M., \& Smol, M. (2014b). Comparison of post-process coke wastewater treatment effectiveness in integrated and hybryd systems that combine coagulation, ultrafiltration, and reverse osmosis. Desalination and Water Treatment, 52(19-21), 3879-3888.

Obidoska, G., Kalinowski, M., \& Karaczun, Z. (2015). Toxicity and genotoxicity of Vistula River waters in Warsaw before and after the completion of the municipal wastewater transporting system to Czajka treatment plant (Toksyczność i genotoksyczność wód Wisły w Warszawie przed i po uruchomieniu układu przesyłowego ścieków do oczyszczalni Czajka). Inżynieria $i$ Ochrona Środowiska, 18(1), 35-41 (in Polish).

Oulego, P., Collado, S., Garrido, L., Laca, A., Rendueles, M., \& Diaz, M. (2014). Wet oxidation of real coke wastewater containing high thiocyanate concentration. Journal of Environmental Management, 132, 16-23.

Paździor, K., Wrębiak, J., Klepacz-Smółka, A., Gmurek, M., Bilińska, L., Kos, L., Sojka-Ledakowicz, J., \& Ledakowicz, S. (2016). Influence of ozonation and biodegradation on toxicity of industrial textile wastewater. Journal of Environmental Management. https://doi.org/10.1016/j. jenvman.2016.06.055.

Pillai, I. M. S., \& Gupta, A. K. (2016). Anodic oxidation of coke oven wastewater: Multiparameter optimization for simultaneous removal of cyanide, COD and phenol. Journal of Environmental Management, 176, 45-53.

Placek, A., Grobelak, A., \& Kacprzak, M. (2016). Improving the phytoremediation of heavy metals contaminated soil by use of sewage sludge. International Journal of Phytoremediation, 18(6), 605-618. 
Qi R., Yang K., Yu Z. X. (2007). Treatment of coke plant wastewater by SND fixed biofilm hybrid system. Journal of Environmental Sciences, 19(2): 153-159.

Regulation Minister of Environment of 18 November 2014 on conditions to be met for the introduction of sewage into the water or the ground, and the substaces particulary harmful to the aquatic enviroment (Jurnal of law 2014, item. 1800). (in Polish).

Regulation the Minister of Housing of 14 July 2006 on how the responsibilities of suppliers of industrial wastewater and conditions for entry wastewaters into sewers (Jurnal of law 2006, no. 136, item. 964). (in Polish).

Rorat, A., Kachamakova-Trojanowska, N., Jozkowicz, A., Kruk, J., Cocquerelle, C., Vandenbulcke, F., Santocki, M., \& Plytycz, B. (2014). Coelomocyte-derived fluorescence and DNA markers of composting earthworm species. Journal of Experimental Zoology Part A: Ecological Genetics and Physiology, 321(1), 28-40.

Sindera, P., Felis, E., \& Wiszniowski, J. (2011). Genotoxicity of coke wastewaters (Ocena genotoksyczności ścieków koksowniczych). Scientific Review-Engineering and. Environmental Sciences, 53, 217-225 (in Polish).

Smol M., Włodarczyk-Makuła M. (2015). The treatment of industrial wastewater in accordance to 'Zero Waste' strategy, Acta Innovation, 16(5), 5-11.

Smol, M., \& Włodarczyk-Makuła, M. (2017). Effectiveness in the removal of organic compounds from municipal landfill leachate in integrated membrane systems: coagulation NF/RO. Polycyclic Aromatic Compounds, 69, 335-343.

Smol, M., Włodarczyk-Makuła, M., Bohdziewicz, J., \& Mielczarek, K. (2014a). Comparison of the retention of selected PAHs from municipal landfill leachate by RO and UF processes. Desalination and Water Treatment, 52(19-21), 3889-3897.

Smol, M., Włodarczyk-Makuła, M., Bohdziewicz, J., \& Mielczarek, K. (2014b). The use of integrated mambrane systems in the removal of selected pollutants from pretreated wastewater in coke plant. In M. Bodzek \& J. Pelczar (Eds.), Membranes and Membrane Processes in Environmental Protection, red (Vol. 119, pp. 143-152). Warsaw-Gliwice: Monographs of the Environmental Engineering Committee Polish Academy of Sciences.

Smol, M., Kulczycka, J., \& Kowlaski, Z. (2016a). Sewage sludge ash (SSA) from small and large incineration plants as a potential source of phosphorus-Polish case of study. Journal of Environmental Management, 184(3, 617-628.

Smol, M., Włodarczyk-Makuła, M., Mielczarek, K., Bohdziewicz, J., \& Włóka, D. (2016b). The use of reverse osmosis in the removal of PAHs from municipal landfill leachate. Polycyclic Aromatic Compounds, 36(1), 20-39.

Smol, M., Włodarczyk-Makuła, M., \& Skowron-Grabowska, B. (2017). PAHs removal from municipal landfill leachate using an integrated membrane system in aspect of legal regulations. Desalination and Water Treatment, 69, 335-343.

Smółka B., Morel J., Sobolewski A., Latkowska B. (2003). Evaluation of the state of the techniques used in Przyjaźn Coking Plant in the light of reference documents of the best available techniques in the production of iron and steel. Karbo, 23-26.

Tomaszewska, B., \& Bodzek, M. (2013a). The removal of radionuclides during desalination of geothermal waters containing boron using the BWRO system. Desalination, 309, 284-290.
Tomaszewska, B., \& Bodzek, M. (2013b). Desalination of geothermal waters using a hybrid UF-RO process. Part I: Boron removal in pilot-scale tests. Desalination, 319, 99-106.

Trojanowska-Olichwer, A. (2013). Assessment of sediment toxicity from the Włocławski reservoir. Journal of Ecology and Health, 17(3), 103-109.

Turek, A., Włodarczyk-Makuła, M., \& Bajdur, W. M. (2016). Effect of catalytic oxidation for removal of PAHs from aqueous solution. Desalination and Water Treatment, 57(3), 1286-1296.

Vázquez, I., Rodriguez-Iglesias, J., Maranon, E., Castrillón, L., \& Alvarez, M. (2007). Removal of residual phenols from coke wastewater by adsorption. Journal of Hazardous Materials, 147(1), 395-400.

Wei, X. X., Zhang, Z. Y., Fan, Q. L., Yuan, X. Y., \& Guo, D. S. (2012). The effect of treatment stages on the coking wastewater hazardous compounds and their toxicity. Journal of Hazardous Materials, 239, 135-141.

Włodarczyk-Makuła, M., Wiśniowska, E., Turek, A., \& Obstój, A. (2016). Removal of PAHs from coking wastewater during photodegradation process. Desalination and Water Treatment, 57(3), 1262-1272.

Włóka, D., Kacprzak, M., Rosikoń, K., \& Fijałkowski, K. (2013). A study of migration of polycyclic aromatic hydrocarbons in a sewage sludge-soil system. Environment Protection Engineering, 39(2), 115-124.

Włóka, D., Placek, A., Rorat, A., Smol, M., \& Kacprzak, M. (2017). The evaluation of polycyclic aromatic hydrocarbons (PAHs) biodegradation kinetics in soil amended with organic fertilizers and bulking agents. Ecotoxicology and Environmental Safety, 145, 161-168, 2017.

Wu, X., Yang, Y., Wu, G., Mao, J., \& Zhou, T. (2016). Simulation and optimization of a coking wastewater biological treatment process by activated sludge models (ASM). Journal of Environmental Management, 165, 235-242.

Zhang, M., Tay, J. H., Qian, Y., \& Gu, X. S. (1998). Coke plant wastewater treatment by fixed biofilm system for COD and NH 3-N removal. Water Research, 32(2), 519-527.

Zhao, W. T., Huang, X., \& Lee, D. J. (2009a). Enhanced treatment of coke plant wastewater using an anaerobic-anoxic-oxic membrane bioreactor system. Separation and Purification Technology, 66(2), 279-286.

Zhao, W. T., Huang, X., Lee, D. J., Wang, X. H., \& Shen, Y. X. (2009b). Use of submerged anaerobic-anoxic-oxic membrane bioreactor to treat highly toxic coke wastewater with complete sludge retention. Journal of Membrane Science, 330(1), 57-64.

Zhao, W. T., Shen, Y. X., Xiao, K., \& Huang, X. (2010). Fouling characteristics in a membrane bioreactor coupled with anaerobic-anoxic-oxic process for coke wastewater treatment. Bioresource Technology, 101(11), 3876-3873.

Zhao, J. L., Chen, X. W., Yan, B., Wei, C., Jiang, Y. X., \& Ying, G. G. (2015). Estrogenic activity and identification of potential xenoestrogens in a coking wastewater treatment plant. Ecotoxicology and Environmental Safety, 112, 238-246.

Zhou, S., Watanabe, H., Wei, C., Wang, D., Zhou, J., Tatarazako, N., Masunagac, S., Zhang, Y. (2015). Reduction in toxicity of coking wastewater to aquatic organisms by vertical tubular biological reactor. Ecotoxicology and Environmental Safety, $115,217-222$. 